\title{
Characteristics and Influencing Factors of Microbial Community in Heavy Metal Contaminated Soil under Silicon Fertilizer and Biochar Remediation
}

\author{
Jiachao Zhang $\mathbb{D}^{1,2}$ Yuewei He, ${ }^{1,2}$ Yingchun Fang, ${ }^{2}$ Keqi Zhao, ${ }^{1}$ Nanyi Wang, ${ }^{1}$ Yaoyu Zhou, ${ }^{1}$ \\ Lin Luo, ${ }^{1,2}$ and Yuan Yang $\mathbb{D}^{1}$ \\ ${ }^{1}$ College of Resources and Environment, Hunan Agricultural University, Changsha 410128, China \\ ${ }^{2}$ Hunan Kaidi Engineering Technology co., LTD, Changsha, 410000 Hunan, China \\ Correspondence should be addressed to Jiachao Zhang; jiachao.zhang@163.com and Yuan Yang; yangyuan@hunau.edu.cn
}

Received 16 March 2021; Accepted 10 June 2021; Published 6 July 2021

Academic Editor: Muhammad Raziq Rahimi Kooh Bin Abdullah

Copyright ( 2021 Jiachao Zhang et al. This is an open access article distributed under the Creative Commons Attribution License, which permits unrestricted use, distribution, and reproduction in any medium, provided the original work is properly cited.

\begin{abstract}
Silicon fertilizer and biochar have been widely used to remediate soil contaminated by heavy metals. The effects and mechanism of silicon fertilizer and biochar addition on the heavy metal availability, soil biological properties, and microbial community characteristics need further study in soils contaminated by heavy metals. Therefore, this research determined how silicon fertilizer, biochar, and their combined using affected microbial communities related with nitrogen and phosphorus cycling. The abundance and composition of the microbial community were evaluated by quantitative PCR and phospholipid fatty acid analysis, respectively. Results showed that silicon fertilizer and biochar addition significantly changed soil properties, including $\mathrm{pH}$, total organic carbon, ammonium, nitrate. The $\mathrm{Cd}$ and $\mathrm{Zn}$ speciation were significantly reduced by silicon fertilizer, biochar, and their integrated application. Microbial community abundance and structure were also significantly changed. Principal component analysis shows that the difference in soil microbial community structure is the most obvious under the combined addition of biochar, silicon fertilizer and biochar. In addition, the results of fluorescence quantitative PCR showed that with biological addition, the number of soil bacteria was significantly reduced. This study reveals the influence of silicon fertilizer and biochar on bacterial and fungal communities in heavy metal soils and the effect of soil heavy metal availability.
\end{abstract}

\section{Introduction}

Heavy metal pollution is a common environmental problem, which has a serious negative impact on surrounding ecological environments and human health $[1,2]$. Human production activities (such as agricultural fertilizer application, chemical industry manufacturing, mineral mining) are the main factor for the accumulation of heavy metals in the soil [3]. About $10 \%$ of farmland in China was contaminated by different kinds and levels of heavy metals [4]. The heavy metal pollution in soils is becoming more serious, making the government unable to bear the risks of losing more arable land. Effective measures must be taken to repair the soil contaminated by heavy metals and restore its functions.

In order to solve the problem of heavy metal pollution, a large number of remediation strategies have been widely used
$[5,6]$. It is imperative task to select and improve remediation techniques and materials, as some of them were potentially hazardous or costly for soil quality $[7,8]$. Silicon (Si) is one of the most abundant elements in the pedosphere, and can be used as fertilizer and soil conditioner. Silicon fertilizer is a kind of calcium silicate - based slightly alkaline, weak acid soluble vitreous fertilizer. At present, there are two main types of silicon fertilizers produced and applied in China: synthetic silicon fertilizers and silicon fertilizers processed from various industrial solid wastes. Silicon fertilizer has been widely shown to be effective in the remediation of heavy metal contamination, and increase agricultural production and crop yields [9-11]. Previous study showed that $\mathrm{Si}$ addition reduced the bioavailability of heavy metals in soils and their stress on plants [12]. Wang et al. found that silicon fertilizer significantly increased the yield of Chinese cabbage 
and reduced the content of heavy metals [13]. Biochar is obtained by pyrolysis under high temperature and low oxygen conditions. Due to its special adsorption characteristics, it has been widely used in soil heavy metal remediation [14]. Biochar amendment in soils increased cation exchange capacity, promoted nutrients fixation $[6,15]$. Biochar has many extraordinary adsorption characteristics by different functional groups, high pore structures, large specific surface areas. The application of biochar can weaken the mobility of heavy metals in soils, thus reducing their environmental and ecological risk [16].

Soil microorganisms are the general term for bacteria, fungi, actinomycetes, and algae living in the soil, which play an important role in nutrient conversion and cycling. Microbial communities in soil were sensitive to metalinduced stress, and often used as important indicators of heavy metal pollution [3, 17]. Physical and chemical parameters will be changed by silicon fertilizer and biochar addition in heavy metal-contaminated soil. Many studies have found that the application of silicon fertilize and biochar in soil effectively changed the diversity and structure of microbial population $[13,18]$. Biochar can reduce the soil enzyme activity, which may be due to the direct addition of biochar to the microbial impact and thus affect the enzyme production [16]. For example, biochar addition inhibits the catalase, b-glucosidase, and protease activities. However, previous research has shown that biochar activated the activities of soil enzymes, such as urease, invertase, dehydrogenase and alkaline phosphatase [19]. After biochar addition, the community composition of bacteria, fungi and archaea changed to varying degrees in soils, and the activity of nitrifying bacteria and denitrifying bacteria was improved. The addition of biochar significantly stimulated the denitrification genes nirS, nos Z and nirK [6]. The application of silicon fertilizer increased the bacterial community abundance, and provided a better ecological environment for microorganisms in heavy metal contaminated soil [13]. However, little information was available about the biological characteristics in heavy metal-contaminated soil after the combined application of silicon fertilizer and biochar. Thus, we speculate that adding silicon fertilizer and biochar to soil contaminated by heavy metals will change the physical-chemical properties of the soils, such as $\mathrm{pH}$ and electrical conductivity (EC), thus affecting the toxicity of heavy metals and the activity and community structure of soil microbial communities.

Therefore, this study was carried out to determine the physicochemical features, heavy metal availability, and microbial community dynamics in soils polluted by heavy metals after silicon fertilizer and biochar addition. The availability of heavy metals was extracted and determined by ICPMS. The abundance and structure of microbial communities were measured by quantitative PCR and phospholipid fatty acids (PLFAs), respectively. This research will deepen our biological understanding of the impacts of silicon fertilizer and biochar on the physical-chemical properties, effective states of heavy metals, and microbial community dynamics in heavy metal polluted soils.
TABle 1: Physicochemical properties of experimental soil and amendments.

\begin{tabular}{|c|c|c|}
\hline Properties & Soil & Biochar \\
\hline $\mathrm{EC}\left(\mathrm{ds} \cdot \mathrm{m}^{-1}\right)$ & $0.18 \pm 0.01$ & $0.16 \pm 0.01$ \\
\hline $\mathrm{pH}\left(\mathrm{H}_{2} \mathrm{O}\right)$ & $5.16 \pm 0.14$ & $9.10 \pm 0.02$ \\
\hline $\mathrm{OM}\left(\mathrm{g} \cdot \mathrm{kg}^{-1}\right)$ & $70.8 \pm 0.8$ & $816.20 \pm 4.23$ \\
\hline TOC $\left(g \cdot k^{-1}\right)$ & $41.07 \pm 0.46$ & $473.44 \pm 2.45$ \\
\hline $\mathrm{NH}_{4}^{+}-\mathrm{N}\left(\mathrm{mg} \cdot \mathrm{kg}^{-1}\right)$ & $34.32 \pm 2.2$ & $42.20 \pm 1.39$ \\
\hline $\mathrm{NO}_{3}^{-}-\mathrm{N}\left(\mathrm{mg} \cdot \mathrm{kg}^{-1}\right)$ & $21.67 \pm 0.23$ & $6.98 \pm 1.59$ \\
\hline Total as $\left(\mathrm{mg} \cdot \mathrm{kg}^{-1}\right)$ & $72.4 \pm 2.01$ & $4.25 \pm 0.16$ \\
\hline Total cd (mg.kg-1) & $0.51 \pm 0.01$ & $0.15 \pm 0.01$ \\
\hline Total cu (mg.kg-1) & $52.6 \pm 2.29$ & $301.62 \pm 0.89$ \\
\hline Total Zn (mg.kg $\left.{ }^{-1}\right)$ & $144.9 \pm 3.13$ & $483.47 \pm 13.75$ \\
\hline Ash content (\%) & - & $49.52 \pm 1.23 \%$ \\
\hline Specific surface area $\left(\mathrm{m}^{2} \cdot \mathrm{g}^{-1}\right)$ & $0.69 \pm 0.05$ & $60.18 \pm 3.12$ \\
\hline Moisture (\%) & 18.65 & 7.12 \\
\hline
\end{tabular}

Numbers are presented as means \pm standard deviations (SD).

\section{Materials and Methods}

2.1. Soil Samples and Raw Materials. Soil samples were collected from Liuyang of Changsha City, Hunan, China. As a result of mining and agricultural activities, soils are contaminated by heavy metals such as arsenic (As), cadmium (Cd), copper $(\mathrm{Cu})$ and zinc $(\mathrm{Zn})$. Soils $(0-20 \mathrm{~cm})$ were collected and transported to the laboratory. After removal of visible stones and plant residues, soils were air-dried to a constant weight, then sifted through a $2 \mathrm{~mm}$ sieve. Biochar was produced by pyrolyzing rice straw under oxygen-limited conditions $\left(500^{\circ} \mathrm{C}, 3 \mathrm{~h}\right)$ [6]. Silicon fertilizer was provided by Hunan Academy of Agricultural Sciences (Slag, watersoluble silicon fertilizer content $4.6 \pm 1.5$ (g.kg-1), $\mathrm{pH} 8.2$ ). The physico-chemical properties of soil and biochar are shown in Table 1.

2.2. Experimental Description and Sampling. The four treatments were as follow: treatment A (control groups), treatment $\mathrm{B}$ added with silicon fertilizer $(0.5 \%)$, treatment C added with biochar $(2 \%)$, treatment $\mathrm{D}$ added with silicon fertilizer and biochar $(0.5 \%$ and $2 \%)$. All the soil was cultured in an artificial incubator, the moisture was adjusted to about $70 \%$ with ultrapure water, and the temperature is maintained at about $25 \pm 2^{\circ} \mathrm{C}$ for 100 days. Samples for molecular analysis and physico-chemical properties were separately reposited at $-20^{\circ} \mathrm{C}$ and $4^{\circ} \mathrm{C}$, respectively. A specific surface area instrument (Gemini-2390) was used to determine the specific surface area of the sample. Before analysis, perform vacuum deoxidation was carried out at a temperature of $180^{\circ} \mathrm{C}$. In a $77 \mathrm{~K}$ high-purity liquid nitrogen environment, multi-point BET method was used to calculate the specific surface area.

2.3. Soil Physico-Chemical Property Measurements. Moisture content was determined by drying at $105^{\circ} \mathrm{C}$ for $24 \mathrm{~h}$. Soil $\mathrm{pH}$ and $\mathrm{EC}$ were determined by using a digital $\mathrm{pH}$ meter (for water/soil ratio of $2.5: 1) \quad[20,21]$. Ammonium nitrogen $\left(\mathrm{NH}_{4}^{+}-\mathrm{N}\right)$ and nitrate nitrogen $\left(\mathrm{NO}_{3}^{-}-\mathrm{N}\right)$ were extracted 
with $2 \mathrm{M} \mathrm{KCl}$ (Analytically pure) and examined by flowinjection analyzer $[22,23]$. The organic matter $(\mathrm{OM})$ content was determined by dry combustion, and the total organic carbon (TOC) content was equal to OM/1.724 content [24].

The content of heavy metals extracted by $\mathrm{CaCl}_{2}$ is usually considered as a valid index of metal availability in contaminated soil [16]. The heavy metals in the soil were extracted with $0.01 \mathrm{M} \mathrm{CaCl}_{2}$ (AR) solution, centrifuged and filtered with $0.45 \mu \mathrm{m}$ polyethersulfone membrane. $1 \mathrm{~mL}$ of $1 \mathrm{M}$ $\mathrm{HNO}_{3}$ (AR) solution was added to the filtered solution to reduce microbial activity and avoid heavy metal precipitation. Finally, the concentration of heavy metals in the solution was determined by ICP-MS (PerkinElmer, NexION $300 \times$, USA) [25].

2.4. DNA Extraction and Quantitative PCR. Total genomic DNA of soils was extracted by using the Powersoil kit (MoBio Laboratories, USA). Primers 338F/543R [26] and Uni18S2/Uni18SR2 [27] were selected for bacterial $16 \mathrm{~S} \mathrm{rDNA}$ and fungal $18 \mathrm{~S}$ rDNA, respectively. The PCR reaction system $(20 \mu \mathrm{L})$ contained $10 \mu \mathrm{L}$ of $2 \times$ Power Taq PCR Master Mix (BioTeke, Beijing), $0.5 \mu \mathrm{L}$ of each primer $(10 \mu \mathrm{M}), 0.5 \mu \mathrm{L}$ of DNA extract, and $8.5 \mu \mathrm{L}$ of sterile water. PCR amplification procedures were as follows: $94^{\circ} \mathrm{C}$ for $4 \mathrm{~min}$, followed by 40 cycles of $94^{\circ} \mathrm{C}$ for 30 $\mathrm{s}, 55^{\circ} \mathrm{C}$ for $30 \mathrm{~s}, 72^{\circ} \mathrm{C}$ for $30 \mathrm{~s}$ and $83^{\circ} \mathrm{C}$ for $20 \mathrm{~s}$. The data was retrieved at $83^{\circ} \mathrm{C}$. The linear standard curves for bacterial and fungal community with six magnitude orders were from $1.0 \times 10^{3}$ to $1.0 \times 10^{8}$ copies.

2.5. PLFAs Analysis. Fresh soil sample (2 g) was used to measure the PLFAs with citrate buffer $(0.15 \mathrm{M})$ : methanol: chloroform mixture $(0.8: 1: 2, \mathrm{v} / \mathrm{v} / \mathrm{v})$. After fractionated into glycolipids, neutral lipids and phospholipids in the silicic acid column (Supelco), phospholipids were subjected into mild alkaline methanolysis. Soil sample was put in a $50 \mathrm{~mL}$ centrifuge tube, and added with $15 \mathrm{~mL}$ of $0.2 \mathrm{M} \mathrm{KOH}$ (AR) methanol solution, and incubated in $37^{\circ} \mathrm{C}$ water bath for $1 \mathrm{~h}$. A gas chromatograph (Hewlett-Packard 6890, USA) was used to separate the fatty acid methyl esters by column HP-Ultra 2 with hydrogen as the carrier gas. The flame ionization detector (FID) and the MIDI Microbial Identification System software were used to detect and identify the compounds of fatty acid methyl esters (FAME). PLFAs data was quantified using the internal standard 19:0 and the program PLFA Tools (MIDI) [28].

2.6. Data Analysis. All experimental treatments and data analysis have three replicates. SPSS software (version 22, Chicago, Illinois) and one-way analysis of variance (ANOVA) were used to analyze the soil physical, chemical properties, heavy metal availability and PLFA of the samples under different treatment conditions. The Tukey test was carried out to compare the average values for different treatments on the same sampling time.

\section{Results and Discussion}

3.1. Influence on Soil Physical and Chemical Parameters. The physico-chemical characteristics in different treatments are shown in Figure 1. The $\mathrm{pH}$ was stable and ranged from 5.1 to 6.5. Compared with the control groups, $\mathrm{pH}$ of treatments $\mathrm{B}$, treatments $\mathrm{C}$ and treatments $\mathrm{D}$ on day 100 , were increased by $2.7 \%, 22.2 \%$ and $16.5 \%$, respectively. Previous studies have shown that adding biochar can significantly change the $\mathrm{pH}$ of the soil. Because the carbonate and silicate in the biochar can combine with $\mathrm{H}^{+}$, this will reduce the $\mathrm{H}^{+}$in the soil and water, thereby increasing the $\mathrm{pH}$ of the soil. Biochar gradually released alkali and alkaline metals into soils [29, 30]. The increase in soil $\mathrm{pH}$ caused by the addition of silicon fertilizer may be due to the presence of a large amount of silicate.

It can be seen from Figure 1 that after adding silicon fertilizer, the effect on soil EC is not significant, there is a significant increase $(P<0.05)$ by adding biochar. The decrease in EC value of treatment D from 0 to 100 days may be due to the increase of biochar deposited by mineral salt [31]. After silicon fertilizer addition $\mathrm{NO}_{3}{ }^{-} \mathrm{N}$ rather than $\mathrm{NH}_{4}{ }^{+} \mathrm{N}$ was significantly increased in the soil, indicating that $\mathrm{Si}$ addition promoted the organic nitrogen conservation [32]. The application of biochar has a significant effect on soil TOC (Figure 1(b)). The increase in TOC content may be due to the secretion decomposition by soil microbial communities or the decomposition of organic compounds. This result is consistent with the results of previous studies [16].

3.2. Effects on the form of Available Heavy Metals. The addition of biochar and silicon fertilizer significantly reduced the effective forms of $\mathrm{Cd}$ and $\mathrm{Zn}$, especially in treatments $\mathrm{C}$ and treatments D (Figure 2). By improving biochar and silicon fertilizer, the effective content of $\mathrm{Cd}$ and $\mathrm{Zn}$ in treatments $\mathrm{C}$ and D was significantly decreased compared with the control group on day 100. The reduction of effective forms of $\mathrm{Zn}$ was $93.9 \%$ and $91.7 \%$, and the reduction of effective forms of $\mathrm{Cd}$ also reached $64.5 \%$ and $61.8 \%$. However, by adding silicon fertilizer alone, the effective forms of $\mathrm{Cu}$ and $\mathrm{Zn}$ have been significantly increased, which may be due to the large amount of $\mathrm{Cu}$ and $\mathrm{Zn}$ contained in silicon fertilizer.

Organic matter and $\mathrm{pH}$ are two key factors controlling heavy metal availability in soils. It has been widely indicated that Si amendments decreased bioavailability of heavy metals by increasing $\mathrm{pH}$ in soils $[33,34]$. Our experimental results indicated that the addition of biochar and silicon fertilizer significantly changed the effective form of heavy metals, one important reason might be the increased $\mathrm{pH}$ in soils. As we all know, the effective form analysis of heavy metals in the soil is an important indicator for evaluating the toxicity of heavy metals, and the toxicity of heavy metals in the soil depends on the $\mathrm{pH}$ value of the soil [35]. By adding biochar and silicon fertilizer, the $\mathrm{pH}$ value increased and the passivation of heavy metals in the soil was the key reason for the decrease in the bioavailability of heavy metals. Previous studies have shown that the addition of biochar increased the fixation rate of heavy metals and reduced their bioavailability [36]. The addition of biochar changes the nature of the soil and provides a reaction site for heavy metal redox reactions. The surface of biochar has hydroxyl, carbonyl and carboxyl groups, which are combined with metal ions through complexation. These functional groups on the surface of biochar also provide redox reaction active sites for heavy metal 


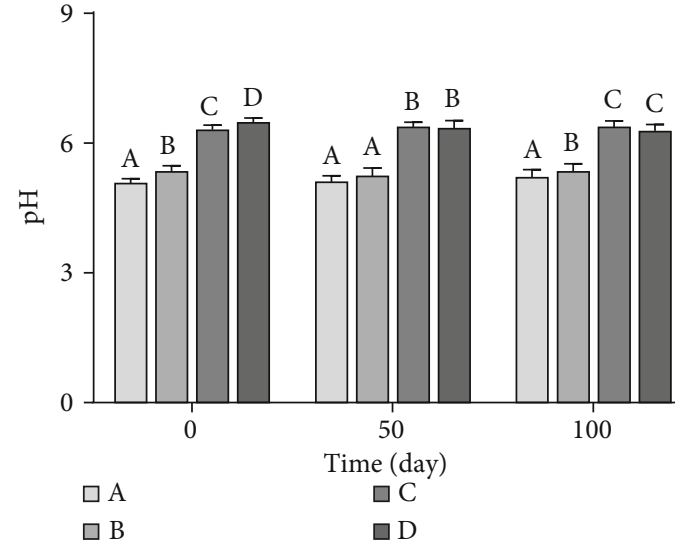

(a)
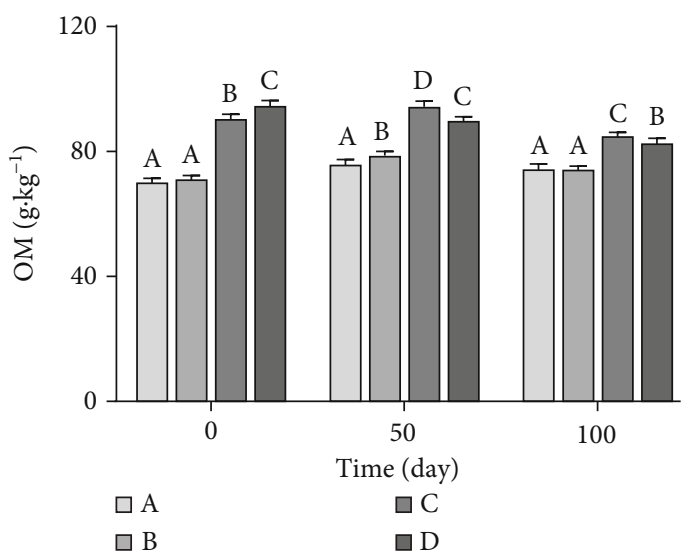

(c)

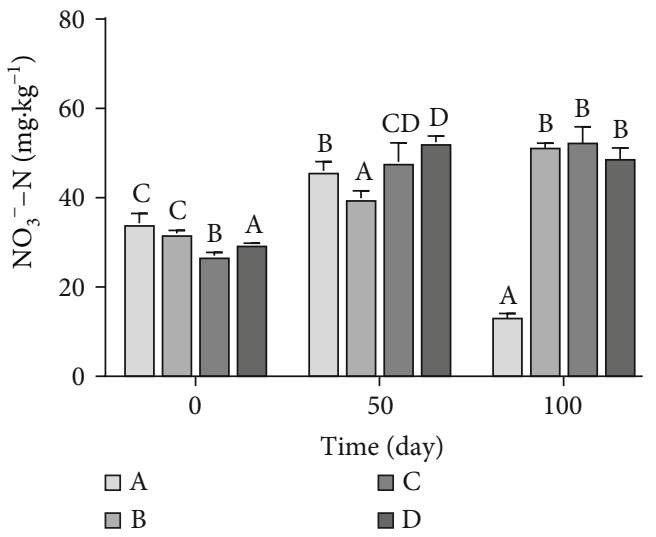

(e)

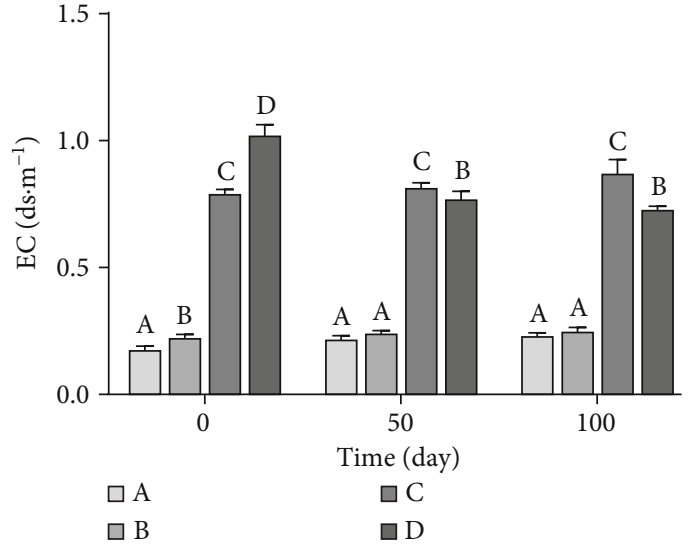

(b)

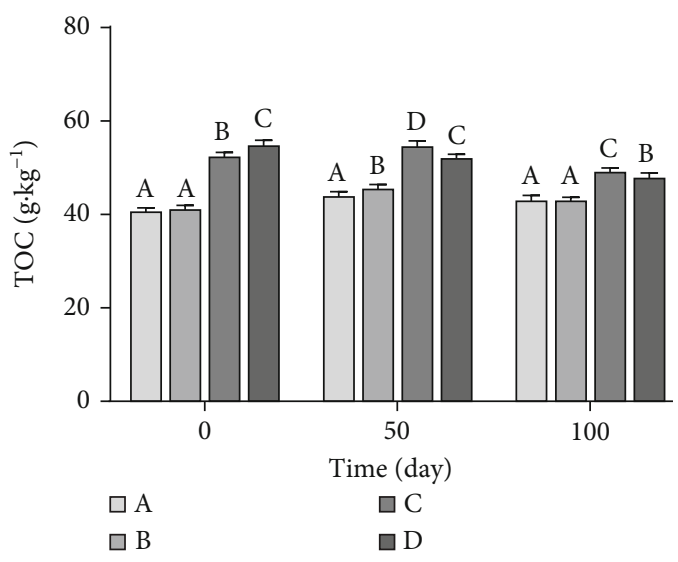

(d)

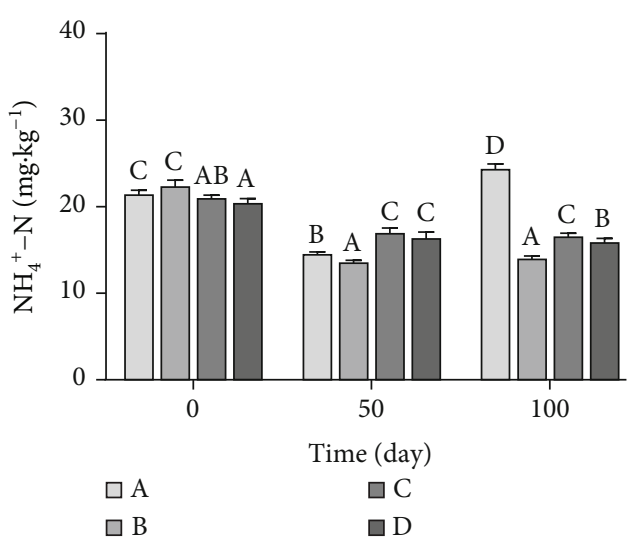

(f)

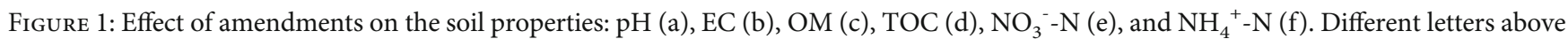
bars indicate significant differences between mean values at each sampling occasion $(P<0.05)$.

through adsorption [21, 29]. Moreover, Si application affected the soil properties thereby controlling the availability of heavy metals $[37,38]$.

3.3. Impact on the Abundance of Microbial Community. By adding silicon fertilizer and biochar, the total amount of soil microbial biomass including algae, bacteria, fungi and protozoa and the abundance of bacterial communities have chan- ged (Figure 3). Adding biochar to the soil significantly reduced the abundance of bacterial communities. However, the addition of silicon fertilizer can increase the abundance of bacterial 16S rRNA genes, and the maximum abundance occurred on day 50 . The abundance of bacterial community in treatments B and treatments D was significantly higher than that in treatments $A$ and treatments $C$, which indicated that the addition of silicon fertilizer and the combined 


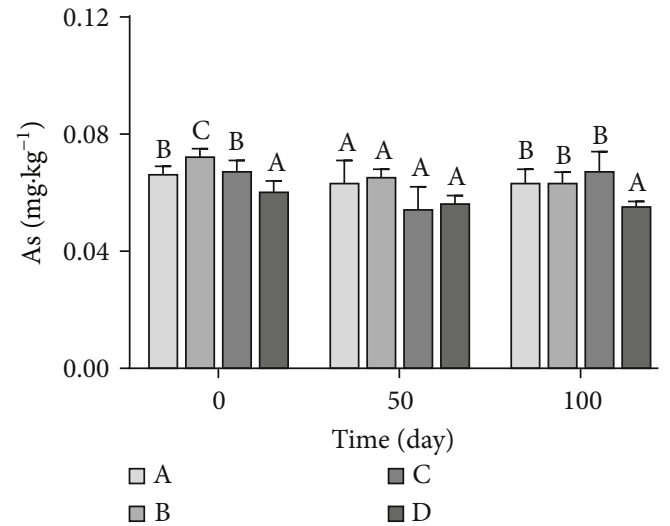

(a)

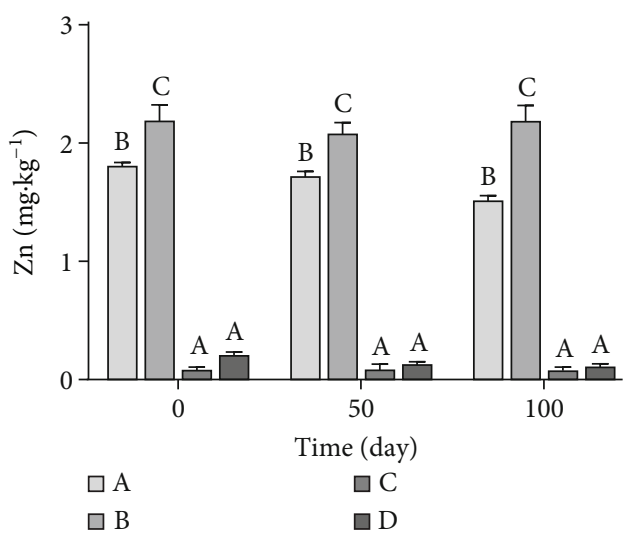

(c)

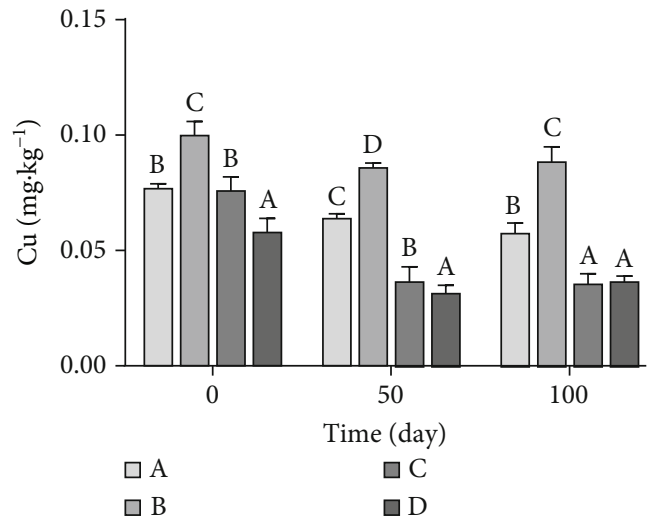

(b)

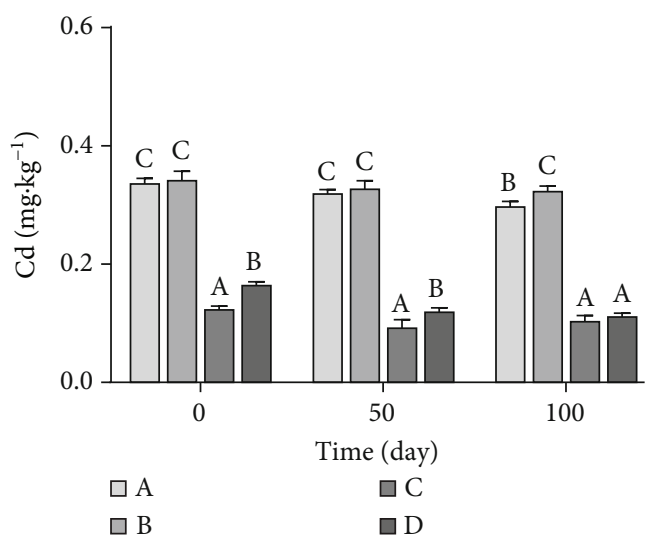

(d)

FIGURE 2: Effect of amendments on the concentration of $\mathrm{CaCl}_{2}$-extractable heavy metals: As (a), Cu (b), $\mathrm{Zn}(\mathrm{c})$, and Cd (d) in soils. Different letters above bars indicate significant differences between mean values at each sampling occasion $(P<0.05)$.

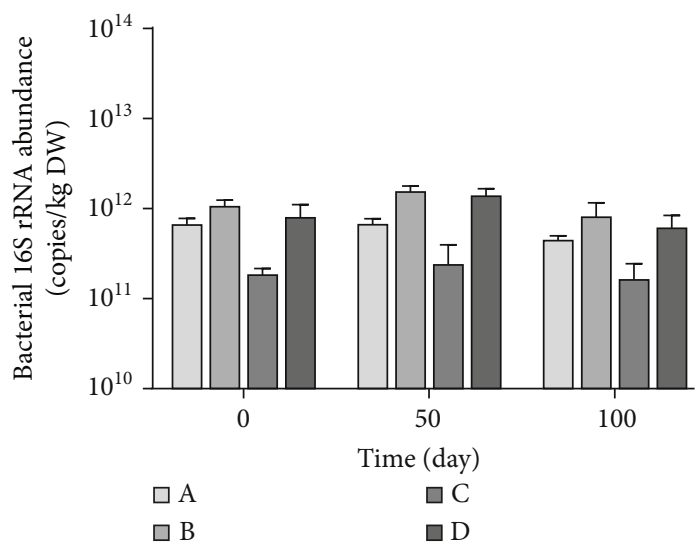

(a)

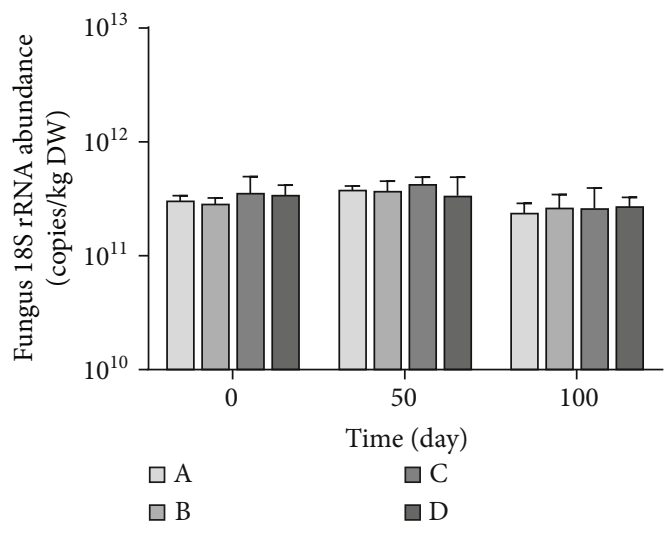

(b)

Figure 3: Bacterial 16S rRNA gene abundance (a), 18S rRNA gene abundance (b) for different treatments. Different letters above bars indicate significant differences $(P<0.05)$ at each sampling occasion.

addition of silicon fertilizer with biochar significantly stimulated the activity of bacteria. However, all treatments had little effect on the gene abundance of fungal $18 \mathrm{~S}$ rRNA.

The abundance and structure of soil microbial communities are highly sensitive to soil changes, and soil changes are often used as indicators of metal pollution [39]. Soil micro- bial community diversity is very rich but in moderately heavy metal-contaminated soil, it has been reduced by more than 1,000 times $[40,41]$. Many reports indicated that soil microbial community abundance and structure have changed under heavy metals stress [42, 43]. Long-term pollution with $\mathrm{Cd}, \mathrm{Zn}$, and $\mathrm{Cu}$ can cause a significant decrease in soil 


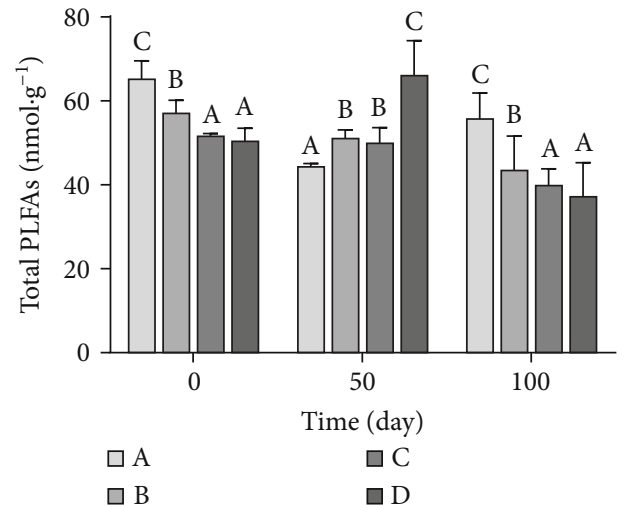

(a)

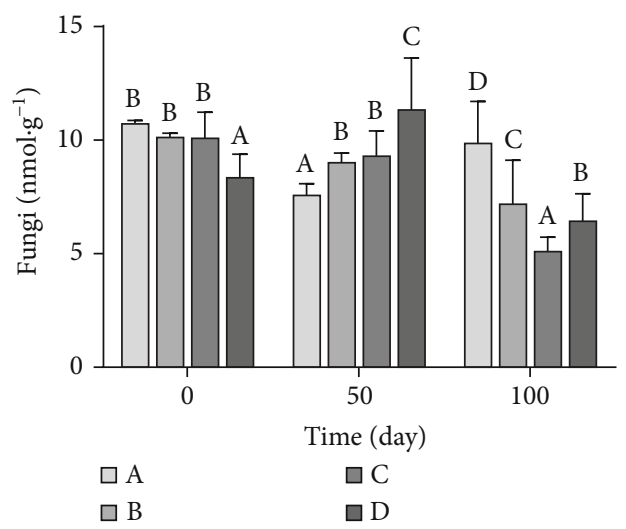

(c)

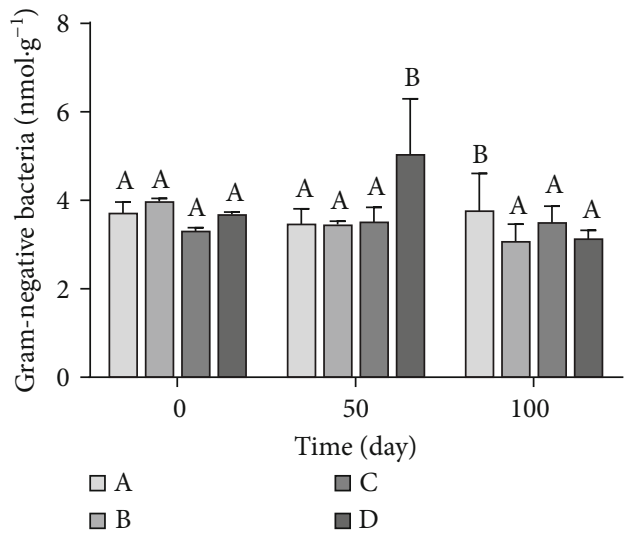

(e)

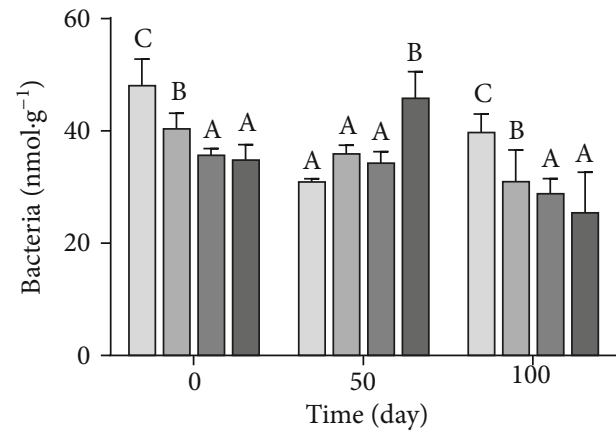

$\square \mathrm{A}$

$\square \mathrm{C}$

$\square B$

(b)

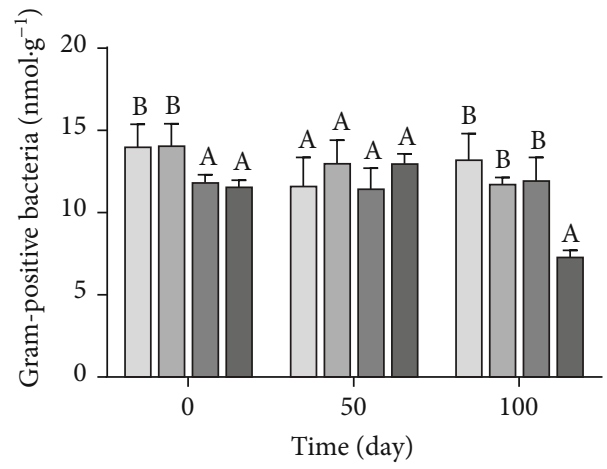

$\square \mathrm{A}$
$\square \mathrm{B}$

$\square \mathrm{D}$

(d)

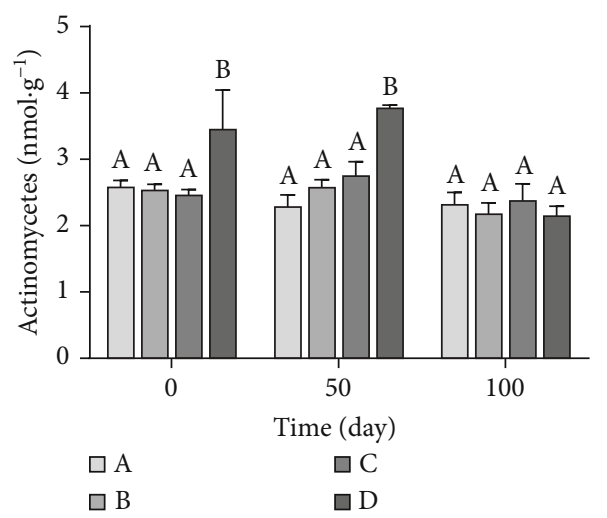

(f)

FIgure 4: Continued. 


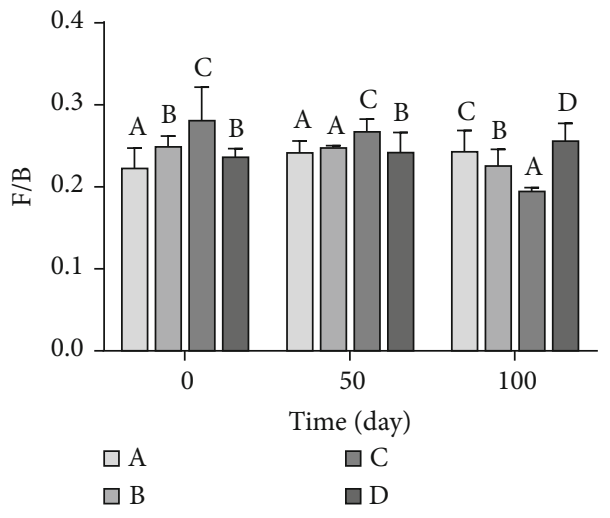

(g)

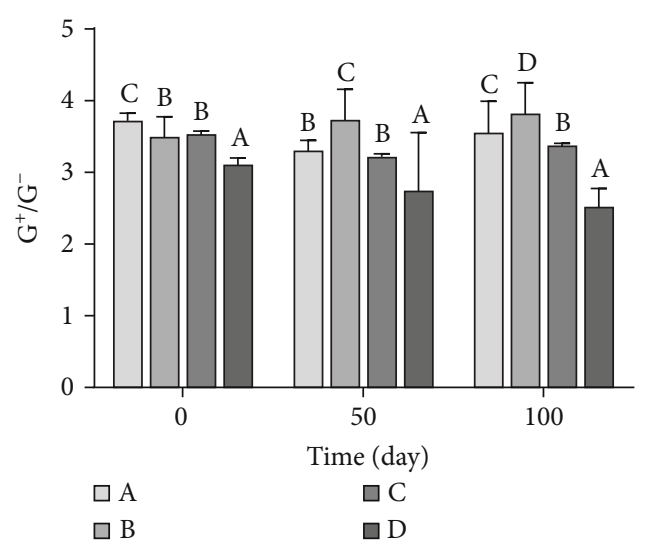

(h)

Figure 4: (a) Total phospholipid fatty acids; (b) bacterial; (c) Fungi; (d) G G $^{+}$Gram-positive bacteria; (e) G G $^{-}$Gram-negative bacteria; (f) Actinomycetes; (g) F/B, the ratio of fungi to bacteria; (h) $\mathrm{G}^{+} / \mathrm{G}^{-}$, the ratio of Gram-positive bacteria to Gram-negative bacteria for different treatments. Different letters above bars indicate significant differences $(P<0.05)$ at each sampling occasion.

microbial diversity $[44,45]$. Basal respiration was significantly $(P \leq 0.05)$ lower in the heavily contaminated soils as compared to the weakly contaminated and control soils [46]. A total of 6 bacterial phyla were detected, which were Acidobacteria (57.7\%), Proteobacteria (29.6\%), Bacteroidetes (5.6\%), Firmicutes (4.2\%), Actinobacteria (1.4\%), Nitrospira (1.4\%), respectively. However, DNA band profiles of the remediated soils which indicated by single-strand conformation polymorphism analysis were in higher number than in the untreated soils [46]. The toxicity of heavy metals to bacterial communities is greater than to fungi [47], which is similar to the results of our experiment, and there is no significant change in the number of fungi.

In general, the abundance and diversity of microorganisms depends on several factors. Among them, the $\mathrm{pH}$ value is a key factor affecting the microbial community and activities. Adding biochar and silicon fertilizer can change the nature of the soil, so it affects the growth and activity of the soil microbial community. Similar results have shown that biochar changed the abundance of bacterial communities [48]. Biochar affects the structure of soil microbial community and is closely related to the toxicity and $\mathrm{pH}$ of heavy metals in the soil. Research proposed that biochar promoted microbial reproduction by providing essential organic substances related to the water stability of soil aggregate sand [49]. The large surface area and porous structure of biochar is suitable habitats for microorganisms. In addition, the silicate in the silicon fertilizer also provides nutrients for the growth of microorganisms [13].

3.4. Dynamic Changes of Characteristic Microbial PLFAs. As shown in Figure 4, in the process of soil culture, the concentration of PLFA corresponding to the main features of total microorganisms, bacteria and fungi in the treatment $\mathrm{C}$ showed a downward trend. For actinomycetes, the influence of PLFA concentration of $\mathrm{G}^{+}$and $\mathrm{G}^{-}$(the main characteristic corresponding to negative bacteria) was minimal. In addition, the Principal Component Analysis (PCA) results showed that the contribution rates of the PCA 1 axis and PCA 2 axis were $46.7 \%$ and 31.9\%, respectively (Figure 5). The distribution of treatment $\mathrm{A}$ and treatment $\mathrm{B}$ is relatively concentrated and the difference is small, indicating that the impact on the PLFA content is not significant. The distribution of treatment $\mathrm{C}$ and treatment $\mathrm{D}$ is very scattered, indicating that the treatment of PLFA has a large impact. These results suggested that the main influence on the PLFA content and structure was the addition of biochar.

In the process of soil cultivation, some related microbial communities preferentially grow and reproduce, and the characteristic PLFAs obtained through their own biochemical pathways are shaped to indicate the dynamic changes of structure and biomass [50]. Many studies have shown that the contents of biomarker PLFA can be used to estimate the biomass of soil microbial community [51-53]. In this study, 28 characteristic PLFAs were detected in the experimental soil, and the typical PLFA with higher content was selected for microbial community analysis among the 21 typical PLFAs. In order to characterize community composition, each fatty acid has been used as a marker for various functional microorganisms. Specifically, the bacterial biomass can be estimated by the total content of the markers14:0, i14:0, 15:0, i15:0, a15:0, 16:0, i16:0, $17: 0$, a17:0, i17:0,18: 0 and $20: 0$ [54]. The total content of fungal biomass is $16:$

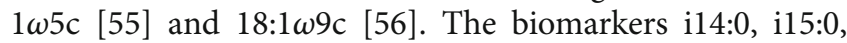
a15:0, i16:0, i17:0 and a17:0 represent the biomass of $\mathrm{G}^{+}$ [57]. The biomarkers 16:0 2OH, 16:1 2OH, 17:1 w8c, cy17:0 and $117: 03 \mathrm{OH}$ represent the biomass of $\mathrm{G}^{-}$[58]. The biomarkers 10Me17:0 and 10Me18:0 were used as indicators of actinomycete biomass [59]. Estimate the total biomass of microorganisms by the sum of all 21 PLFAs determined.

The main reason may be that the addition of biochar leads to obvious changes in soil $\mathrm{pH}$, the activity of microorganisms is inhibited, and a large number of microorganisms die or enter a dormant state [60]. The growth rate of PLFA in bacteria decreased significantly, and the content of PLFA in 


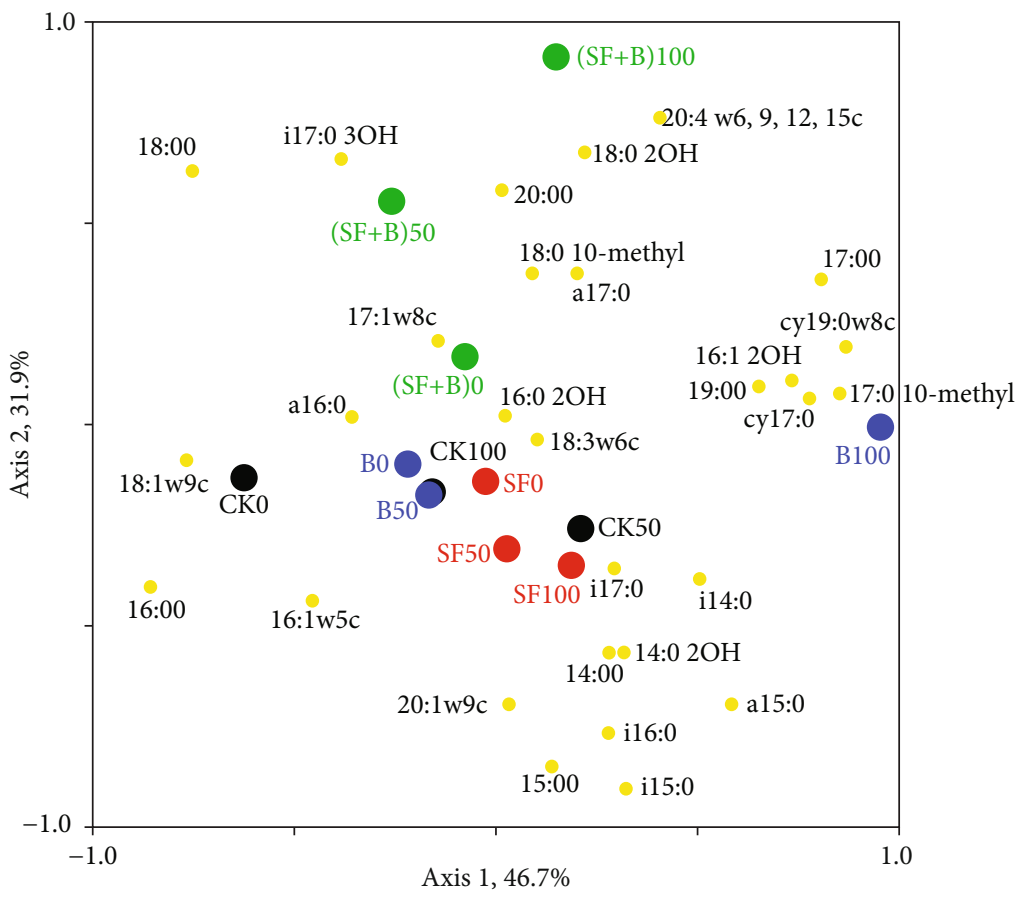

FIGURE 5: Principal component analysis of soil microbial communities based on PLFA biomarkers under different treatments. CK: control group; SF: silicon fertilizer, B: biochar; SF + B: silicon fertilizer and biochar. Numbers 0, 50, and 100 represent the number of days of sampling, respectively.

fungi decreased rapidly. In treatment $\mathrm{D}$, the concentration of PLFA corresponding to the main characteristics of total microorganisms, bacteria, fungi and actinomycetes showed an overall upward and then downward trend, and all reached the peak on the 50th day of culture. The main reason may be that the silicon fertilizer and biochar in the treatment D provide abundant nutrients and growth sites for the growth of microorganisms. During 0 to 50 days of culture, the dominant strains grow rapidly. From 50 to 100 days, it may be due to the proliferation of microorganisms that freely used organic matter is depleted [50], resulting in a gradual decrease in the PLFA content of bacteria, fungi and actinomycetes. Due to the increase in the content of PLFAs, the main characteristic of $\mathrm{G}^{-}$in the treatment $\mathrm{D}$, the $\mathrm{G}+/ \mathrm{G}$ - ratio decreased, which also indicated that the soil environment had a better nutritional status [61].

\section{Conclusions}

The toxicity level of heavy metals ( $\mathrm{Cd}$ and $\mathrm{Zn}$ ) in soils has changed significantly after adding silicon fertilizer and biochar. The addition of biochar significantly changed the $\mathrm{pH}, \mathrm{EC}$ and TOC, and silicon fertilizer promoted the preservation of organic nitrogen. The toxicity level of heavy metals is significantly correlated with $\mathrm{pH}$. The addition of silicon fertilizer and its combination with biochar increased the bacterial community abundance. All additives have little effect on the fungal community abundance. Soil microbial composition indicated by PLFA analysis was significantly changed by the addition of biochar.

\section{Data Availability}

All data generated or analyzed during this study are included in this published article.

\section{Conflicts of Interest}

The authors declared no potential conflicts of interest with respect to the research, authorship, and/or publication of this article.

\section{Acknowledgments}

This work was jointly supported by the Hunan Provincial Key R\&D (2019WK2031 and 2019SK2281), and the National Natural Science Foundation of China (51408219).

\section{References}

[1] X. Yuan, N. Xue, and Z. Han, "A meta-analysis of heavy metals pollution in farmland and urban soils in China over the past 20 years," Journal of Environmental Sciences, vol. 101, pp. 217226, 2021.

[2] G. Qin, Z. Niu, J. Yu, Z. Li, J. Ma, and P. Xiang, "Soil heavy metal pollution and food safety in China: effects, sources and removing technology," Chemosphere, vol. 267, p. 129205, 2021.

[3] J. Tang, J. Zhang, L. Ren et al., "Diagnosis of soil contamination using microbiological indices: a review on heavy metal pollution," Journal of Environmental Management, vol. 242, pp. 121-130, 2019.

[4] S. Kou, G. Vincent, E. Gonzalez, F. E. Pitre, M. Labrecque, and N. J. B. Brereton, "The response of a $16 \mathrm{~S}$ ribosomal RNA gene 
fragment amplified community to Lead, zinc, and copper pollution in a Shanghai field trial," Frontiers in Microbiology, vol. 9, p. 366, 2018.

[5] A. Raklami, A. I. Tahiri, N. Bechtaoui et al., "Restoring the plant productivity of heavy metal-contaminated soil using phosphate sludge, marble waste, and beneficial microorganisms," Journal of Environmental Sciences, vol. 99, pp. 210221, 2021.

[6] M. Li, L. Ren, J. Zhang et al., "Population characteristics and influential factors of nitrogen cycling functional genes in heavy metal contaminated soil remediated by biochar and compost," Science of the Total Environment, vol. 651, pp. 2166-2174, 2019.

[7] Y. Shao, T. Yan, K. Wang, S. Huang, W. Yuan, and F. G. F. Qin, "Soil heavy metal lead pollution and its stabilization remediation technology," Energy Reports, vol. 6, pp. 122-127, 2020.

[8] Y. Wang, A. Li, and C. Cui, "Remediation of heavy metalcontaminated soils by electrokinetic technology: mechanisms and applicability," Chemosphere, vol. 265, p. 129071, 2021.

[9] S. Ali, M. A. Farooq, T. Yasmeen et al., "The influence of silicon on barley growth, photosynthesis and ultra-structure under chromium stress," Ecotoxicology and Environmental Safety, vol. 89, pp. 66-72, 2013.

[10] X. Shen, X. Xiao, Z. Dong, and Y. Chen, "Silicon effects on antioxidative enzymes and lipid peroxidation in leaves and roots of peanut under aluminum stress," Acta Physiologiae Plantarum, vol. 36, no. 11, pp. 3063-3069, 2014.

[11] C. Keller, M. Rizwan, J. C. Davidian et al., "Effect of silicon on wheat seedlings (Triticum turgidum L.) grown in hydroponics and exposed to 0 to $30 \mu \mathrm{M}$ cu," Planta, vol. 241, no. 4, pp. 847860, 2015.

[12] M. Adrees, S. Ali, M. Rizwan et al., "Mechanisms of siliconmediated alleviation of heavy metal toxicity in plants: a review," Ecotoxicology and Environmental Safety, vol. 119, pp. 186-197, 2015.

[13] B. Wang, C. Chu, H. Wei et al., "Ameliorative effects of silicon fertilizer on soil bacterial community and pakchoi (Brassica chinensis L.) grown on soil contaminated with multiple heavy metals," Environmental Pollution, vol. 267, p. 115411, 2020.

[14] D. Huang, L. Liu, G. Zeng et al., "The effects of rice straw biochar on indigenous microbial community and enzymes activity in heavy metal-contaminated sediment," Chemosphere, vol. 174, pp. 545-553, 2017.

[15] Y. Jin, X. Liang, M. He, Y. Liu, G. Tian, and J. Shi, "Manure biochar influence upon soil properties, phosphorus distribution and phosphatase activities: a microcosm incubation study," Chemosphere, vol. 142, pp. 128-135, 2016.

[16] J. Tang, L. Zhang, J. Zhang et al., "Physicochemical features, metal availability and enzyme activity in heavy metalpolluted soil remediated by biochar and compost," Science of the Total Environment, vol. 701, p. 134751, 2020.

[17] J. Wang, Y. Song, T. Ma et al., "Impacts of inorganic and organic fertilization treatments on bacterial and fungal communities in a paddy soil," Applied Soil Ecology, vol. 112, pp. 42-50, 2017.

[18] M. Li, J. Zhang, X. Yang et al., "Responses of ammoniaoxidizing microorganisms to biochar and compost amendments of heavy metals-polluted soil," Journal of Environmental Sciences, vol. 102, pp. 263-272, 2021.

[19] W. Jia, B. Wang, C. Wang, and H. Sun, "Tourmaline and biochar for the remediation of acid soil polluted with heavy metals," Journal of Environmental Chemical Engineering, vol. 5, no. 3, pp. 2107-2114, 2017.

[20] H. Wu, C. Lai, G. Zeng et al., "The interactions of composting and biochar and their implications for soil amendment and pollution remediation: a review," Critical Reviews in Biotechnology, vol. 37, no. 6, pp. 754-764, 2017.

[21] J. Liang, Z. Yang, L. Tang et al., "Changes in heavy metal mobility and availability from contaminated wetland soil remediated with combined biochar-compost," Chemosphere, vol. 181, pp. 281-288, 2017.

[22] J. Zhang, G. Zeng, Y. Chen et al., "Impact of Phanerochaete chrysosporium inoculation on indigenous bacterial communities during agricultural waste composting," Applied Microbiology and Biotechnology, vol. 97, no. 7, pp. 3159-3169, 2013.

[23] N. Liu, P. Liao, J. Zhang et al., "Characteristics of denitrification genes and relevant enzyme activities in heavy-metal polluted soils remediated by biochar and compost," Science of the Total Environment, vol. 739, p. 139987, 2020.

[24] J. Zhang, G. Zeng, Y. Chen et al., "Effects of physico-chemical parameters on the bacterial and fungal communities during agricultural waste composting," Bioresource Technology, vol. 102, no. 3, pp. 2950-2956, 2011.

[25] D. Yin, X. Wang, C. Chen, B. Peng, C. Tan, and H. Li, "Varying effect of biochar on $\mathrm{cd}, \mathrm{Pb}$ and as mobility in a multi-metal contaminated paddy soil," Chemosphere, vol. 152, pp. 196206, 2016.

[26] G. Muyzer, E. C. De Waal, and A. G. Uitterlinden, "Profiling of complex microbial populations by denaturing gradient gel electrophoresis analysis of polymerase chain reactionamplified genes coding for 16S rRNA," Applied and Environmental Microbiology, vol. 59, no. 3, pp. 695-700, 1993.

[27] J. Zhang, G. Zeng, Y. Chen et al., "Phanerochaete chrysosporium inoculation shapes the indigenous fungal communities during agricultural waste composting," Biodegradation, vol. 25, no. 5, pp. 669-680, 2014.

[28] J. S. Buyer, B. Vinyard, J. Maul et al., "Combined extraction method for metabolomic and PLFA analysis of soil," Applied Soil Ecology, vol. 135, pp. 129-136, 2019.

[29] S. Gul, J. K. Whalen, B. W. Thomas, V. Sachdeva, and H. Deng, "Physico-chemical properties and microbial responses in biochar-amended soils: Mechanisms and future directions," Agriculture, Ecosystems \& Environment, vol. 206, pp. 46-59, 2015.

[30] R. Zheng, Z. Chen, C. Cai et al., "Mitigating heavy metal accumulation into rice (Oryza sativa L.) using biochar amendment - a field experiment in Hunan, China," Environmental Science and Pollution Research, vol. 22, no. 14, pp. 11097-11108, 2015.

[31] N. Li, Y. Chen, Z. Zhang et al., "Response of ammoniaoxidizing archaea to heavy metal contamination in freshwater sediment," Journal of Environmental Sciences, vol. 77, pp. 392399, 2019.

[32] N. Ling, C. Zhu, C. Xue et al., "Insight into how organic amendments can shape the soil microbiome in long-term field experiments as revealed by network analysis," Soil Biology \& Biochemistry, vol. 99, pp. 137-149, 2016.

[33] H. H. Gu, H. Qiu, T. Tian et al., "Mitigation effects of silicon rich amendments on heavy metal accumulation in rice (Oryza sativa L.) planted on multi-metal contaminated acidic soil," Chemosphere, vol. 83, no. 9, pp. 1234-1240, 2011.

[34] W. Treder and G. Cieslinski, "Effect of silicon application on cadmium uptake and distribution in strawberry plants grown 
on contaminated soils," Journal of Plant Nutrition, vol. 28, no. 6, pp. 917-929, 2005.

[35] S. K. Sundaray, B. B. Nayak, S. Lin, and D. Bhatta, "Geochemical speciation and risk assessment of heavy metals in the river estuarine sediments-A case study: Mahanadi basin, India," Journal of Hazardous Materials, vol. 186, no. 2-3, pp. 18371846, 2011.

[36] K. Lu, X. Yang, G. Gielen et al., "Effect of bamboo and rice straw biochars on the mobility and redistribution of heavy metals ( $\mathrm{cd}, \mathrm{cu}, \mathrm{Pb}$ and $\mathrm{Zn}$ ) in contaminated soil," Journal of Environmental Management, vol. 186, Part 2, pp. 285-292, 2017.

[37] M. Rizwan, J. D. Meunier, H. Miche, and C. Keller, "Effect of silicon on reducing cadmium toxicity in durum wheat (Triticum turgidum L. cv. Claudio W.) grown in a soil with aged contamination," Journal of Hazardous Materials, vol. 209210, pp. 326-334, 2012.

[38] M. Imtiaz, M. S. Rizwan, M. A. Mushtaq et al., "Silicon occurrence, uptake, transport and mechanisms of heavy metals, minerals and salinity enhanced tolerance in plants with future prospects: a review," Journal of Environmental Management, vol. 183, Part 3, pp. 521-529, 2016.

[39] J. Song, Q. Shen, L. Wang et al., "Effects of cd, cu, Zn and their combined action on microbial biomass and bacterial community structure," Environmental Pollution, vol. 243, Part A, pp. 510-518, 2018.

[40] C. S. Sheik, T. W. Mitchell, F. Z. Rizvi et al., "Exposure of soil microbial communities to chromium and arsenic alters their diversity and structure," PLoS One, vol. 7, no. 6, article e40059, 2012.

[41] J. Berg, K. K. Brandt, W. A. Al-Soud et al., "Selection for cutolerant bacterial communities with altered composition, but unaltered richness, via long-term cu exposure," Applied and Environmental Microbiology, vol. 78, no. 20, pp. 7438-7446, 2012.

[42] J. Yang, J. H. Huang, A. Lazzaro, Y. Tang, and J. Zeyer, "Response of Soil Enzyme Activity and Microbial Community in Vanadium-Loaded Soil," Water, Air, \& Soil Pollution, vol. 225, no. 7, p. 2012, 2014.

[43] C. Li, Q. Quan, Y. Gan et al., "Effects of heavy metals on microbial communities in sediments and establishment of bioindicators based on microbial taxa and function for environmental monitoring and management," Science of the Total Environment, vol. 749, p. 141555, 2020.

[44] Y. Zhang, H. W. Zhang, Z. C. Su, and C. G. Zhang, "Effects of long-term heavy metals stress on farmland soil microbial population, biomass and activity," Ying Yong Sheng Tai Xue Bao, vol. 18, no. 7, pp. 1491-1497, 2007.

[45] B. K. Singh, C. Quince, C. A. Macdonald et al., "Loss of microbial diversity in soils is coincident with reductions in some specialized functions," Environmental Microbiology, vol. 16, no. 8, pp. 2408-2420, 2014.

[46] H. Kaplan, S. Ratering, T. Hanauer, P. Felix-Henningsen, and S. Schnell, "Impact of trace metal contamination and in situ remediation on microbial diversity and respiratory activity of heavily polluted Kastanozems," Biology and Fertility of Soils, vol. 50, no. 5, pp. 735-744, 2014.

[47] R. M. C. P. Rajapaksha, M. A. Tobor-Kapłon, and E. Bååth, "Metal toxicity affects fungal and bacterial activities in soil differently," Applied and Environmental Microbiology, vol. 70, no. 5, pp. 2966-2973, 2004.
[48] J. Harter, H. M. Krause, S. Schuettler et al., "Linking $\mathrm{N}_{2} \mathrm{O}$ emissions from biochar-amended soil to the structure and function of the N-cycling microbial community," The ISME Journal, vol. 8, no. 3, pp. 660-674, 2014.

[49] X. Yang, A. Tsibart, H. Nam et al., "Effect of gasification biochar application on soil quality: trace metal behavior, microbial community, and soil dissolved organic matter," Journal of Hazardous Materials, vol. 365, pp. 684-694, 2019.

[50] N. Liu, J. Zhou, L. Han, and G. Huang, "Characterization of lignocellulosic compositions' degradation during chicken manure composting with added biochar by phospholipid fatty acid (PLFA) and correlation analysis," Science of the Total Environment, vol. 586, pp. 1003-1011, 2017.

[51] K. Kato, N. Miura, H. Tabuchi, and I. Nioh, "Evaluation of maturity of poultry manure compost by phospholipid fatty acids analysis," Biology and Fertility of Soils, vol. 41, no. 6, pp. 399-410, 2005.

[52] C. T. Green and K. M. Scow, "Analysis of phospholipid fatty acids (PLFA) to characterize microbial communities in aquifers," Hydrogeology Journal, vol. 8, no. 1, pp. 126-141, 2000.

[53] H. Chen, X. Zhao, Q. Lin, G. Li, and W. Kong, "Using a combination of PLFA and DNA-based sequencing analyses to detect shifts in the soil microbial community composition after a simulated spring precipitation in a semi-arid grassland in China," Science of the Total Environment, vol. 657, pp. 1237-1245, 2019.

[54] L. Zelles, A. Palojärvi, E. Kandeler, M. von Lützow, K. Winter, and Q. Y. Bai, "Changes in soil microbial properties and phospholipid fatty acid fractions after chloroform fumigation," Soil Biology \& Biochemistry, vol. 29, no. 9-10, pp. 1325-1336, 1997.

[55] P. A. Olsson, E. Bååth, I. Jakobsen, and B. Söderström, “The use of phospholipid and neutral lipid fatty acids to estimate biomass of arbuscular mycorrhizal fungi in soil," Mycological Research, vol. 99, no. 5, pp. 623-629, 1995.

[56] A. Frostegård and E. Bååth, "The use of phospholipid fatty acid analysis to estimate bacterial and fungal biomass in soil," Biology and Fertility of Soils, vol. 22, no. 1-2, pp. 59-65, 1996.

[57] D. A. Bossio, J. A. Fleck, K. M. Scow, and R. Fujii, "Alteration of soil microbial communities and water quality in restored wetlands," Soil Biology \& Biochemistry, vol. 38, no. 6, pp. 1223-1233, 2006.

[58] S. T. Hamman, I. C. Burke, and M. E. Stromberger, "Relationships between microbial community structure and soil environmental conditions in a recently burned system," Soil Biology \& Biochemistry, vol. 39, no. 7, pp. 1703-1711, 2007.

[59] L. Zelles, "Phospholipid fatty acid profiles in selected members of soil microbial communities," Chemosphere, vol. 35, no. 1-2, pp. 275-294, 1997.

[60] H.-T. Wang, J. Ding, Q.-Q. Chi et al., "The effect of biochar on soil-plant-earthworm-bacteria system in metal(loid) contaminated soil," Environmental Pollution, vol. 263, p. 114610, 2020.

[61] Q. Q. Wang, L. L. Liu, Y. Li et al., "Long-term fertilization leads to specific PLFA finger-prints in Chinese Hapludults soil," Journal of Integrative Agriculture, vol. 19, no. 5, pp. 1354$1362,2020$. 